\section{idenoture}

Jurnal Kajian Manajemen Dakwah
Volume 3, Nomor 2, April 2021

P-ISSN: 2654-4695

E-ISSN: 2654-7651

DOI: http://dx.doi.org/10.24014/idarotuna.v3i2.12622

\title{
Aktivitas Dakwah di Kalangan Anak Muda Muslim Pekanbaru
}

\author{
Alfikri, Imron Rosidi \\ Universitas Islam Negeri Sultan Syarif Kasim Riau \\ Email: fikrizukri2@gmail.com
}

\begin{abstract}
Departing from the phenomenon of the increasing da'wah movement of young people in Pekanbaru City, this study analyzes the activity of da'wah in the Community of Mosque Youth and Student Silaturrahim Forum (FSRMM). The main question that will be answered in this research is how the da'wah activities are carried out by FSRMM among young people in Pekanbaru City. This study uses a qualitative approach. Data are collected from interviews, observation and documentation. The results of this study explain that the da'wah activities carried out by the FSRMM include three things, namely: First, Da'wah Bil-Lisan (oral da'wah). The verbal preaching carried out by the FSRMM includes Halaqoh and Tahsin, Tabligh Akbar, preaching via Youtube and Instagram videos. Second, Da'wah Bil-Qolam (written da'wah) is carried out by FSRMM, namely through da'wah posters. Third, da'wah Bil-Hal (action da'wah) is carried out by the FSRMM through social actions such as giving donations to orphans, providing basic necessities, masks and others. Of the three methods of da'wah above, the method that plays an important role in the FSRMM is the Bil- lisan (oral) method of preaching, which focuses on social media, one of which is Youtube and Instagram videos.
\end{abstract}

Keywords: Dakwah Activity, Young Muslims, and FSRMM.

Abstrak: Berangkat dari fenomena gerakan dakwah anak muda Kota Pekanbaru yang semakin meningkat, penelitian ini mengangkat tentang aktivitas dakwah di komunitas Forum Silaturrahim Remaja Masjid dan Mahasiswa (FSRMM). pertanyaan utama yang akan dijawab di dalam penelitian ini adalah bagaimana aktivitas dakwah yang dilakukan FSRMM di kalangan anak muda Kota Pekanbaru. Penelitian ini menggunakan pendekatan kualitatif dengan teknik pengumpulan data melalui wawancara, observasi dan dokumentasi. hasil penelitian ini menjelaskan bahwa aktivitas dakwah yang dilakukan FSRMM meliputi tiga hal yaitu: Pertama, Dakwah Bil-Lisan. Dakwah bil-lisan yang dilakukan FSRMM meliputi Halaqoh dan Tahsin, Tabligh Akbar, dakwah melalui Youtube dan video instagram. Kedua, Dakwah Bil-Qolam. dakwah bil-qolam yang dilakukan oleh FSRMM yaitu melalui poster dakwah. Ketiga, Dakwah Bil-Hal. dakwah bil-hal yang dilakukan FSRMM melalui aksi-aksi sosial seperti memberikan samtunan kepada Anak Yatim, pemberian sembako, masker dan lainnya. Dari ketiga metode dakwah di atas, metode yang sangat berperan penting di FSRMM yaitu metode dakwah Bil-lisan yaitu berfokus di media sosial salah satu nya Youtube dan Video Instagram.

Kata Kunci: Aktivitas Dakwah, Anak Muda, dan FSRMM.

\section{Pendahuluan}

Artikel ini membahas tentang gerakan dakwah anak muda di Kota Pekanbaru. sejak beberapa waktu belakangan ini gerakan dakwah di Pekanbaru meningkat secara signifikan. Beberapa gerakan dakwah tersebut di antaranya Fodamara, FSRMM, dan Sahabaat Hijrah. Artikel ini memfokuskan pada gerakan dakwah FSRMM (Forum Silaturrahim Remaja Masjid dan 
Mahasiswa). Pertanyaaan utama yang akan dijawab di dalam artikel ini adalah Bagaimana Aktivitas Dakwah yang dilakukan oleh FSRMM (Forum Silaturrahim Remaja Masjid dan Mahasiswa) di kalangan anak muda Kota Pekanbaru?

Studi-studi mengenai gerakan dakwah anak muda telah banyak dikaji oleh peneliti sebelumnya di antaranya; pertama, studi yang dilakukan Dony Arung Triantoro yang berjudul "Dakwah dan Kesalehan: Studi tentang gerakan Teras dakwah di Kota Yogyakarta." Dalam studinya, Triantoro membahas tentang kemunculan gerakan dakwah kontemporer di Yogyakarta. Melalui studi lapangan, Triantoro menemukan bahwa gerakan dakwah kontemporer di Yogyakarta yaitu Teras Dakwah mengemas program dakwahnya dengan simbol budaya populer (Triantoro, 2018: 273).

Kedua, studi yang dilakukan Syamsul Rijal yang berjudul "Kaum Muda Pencinta Habaib: Kesalehan Populer dan Ekspresi Anak Muda di Ibu Kota". Dalam studinya, Rijal membahas tentang meningkatnya popularitas penceramah yang berketurunan Arab Hadramaut (Yaman) di kalangan Anak Muda Muslim di Indonesia. Melalui analisis struktural dan kultural Rijal berargumen bahwa keikutsertaaan anak muda di majelis Habaib bukan hanya untuk belajar agama dan memperoleh naungan spiritual, namun juga untuk mengekspresikan "Kemudaan" dengan rekan seusia mereka di tengah kehidupan di kota yang penuh masalah dan tantangan hidup (Rijal, 2018: 166).

Ketiga, studi yang dilakukan Putri Hidayati dkk yang berjudul "Aktivitas Dakwah Komunitas Muslim Bikers Indonesia (KOMBI) Pekanbaru". Dalam studinya, Hidayati membahas munculnya Komunitas Muslim Bikers (KOMBI) di Pekanbaru, terutama pada aspek social dan gerakan dakwahnya. Melalui Studi Lapangan dan didukung dengan literatur yang relevan. Hidayati dkk menemukan hasil dari kajian tersebut menunjukkan bahwa program-program yang dilakukan Komunitas Muslim Bikers (KOMBI) Pekanbaru yang merupakan hal yang positif yang memberikan manfaat bagi masyarakat. (Hidayati dkk, 2020: 1).

Keempat, Studi yang dilakukan Uwes Fatoni dan Annisa Nafisah Rais yang berjudul "Pengelolaan Kesan Da i Dalam Kegiatan Dakwah Pemuda Hijrah". Dalam studinya membahas tentang fenomena da`i yang meramaikan Majlis Ta`lim dengan cara yang khas yang menggembirakan. Melalui penelitian Teori Pengelolaan kesan (Impression Management) dengan pendekatan kualitatif. Uwes Fatoni dan Annisa Nafisah Rais menemukan hasil dari kajian tersebut menunjukkan bahwa Ustad Handy Bonny melakukam pengelolaan kesan dengan baik dan menghasilkan citra yang baik di depan publik, Ustaz Handy Bonny juga berpenampilan secara casual yang sehingga mudah diterima oleh anak muda.(Fatoni \& Rais, 2018: 1)

Kelima, studi yang dilakukan Fathayatul Husna yang berjudul "Pemuda Hijrah: Anak Muda dan Dakwah Online". Dalam studi ini, ia membahas tentang konsep dakwah anak muda melalui media Instagram. Pendekatan metode penelitian ini adalah kualitatif dan mengangkat isu negosisasi generasi Muslim milenial dan kekuatan media. Fathayatul Husna menemukan hasil 
Penelitian tersebut bahwa pemuda Hijrah aktif menggunakan Instagram sebagai perantara mereka untuk berda`wah Islam secara kontemporer (Husna, 2020: 1)

Terakhir, studi yang dilakukan oleh Rosidi (2020). Dalam artikel ini, Rosidi menjelaskan tentang konsumsi produk budaya anak muda Muslim di Pekanbaru dan identitas Islam dalam konteks globalisasi. Artikel ini menunjukan bahwa globalisasi perlu dikaji dalam konteks lokal di mana ketersediaan produk budaya global ternyata berbaur dengan dukungan kuat dari nilai-nilai lokal yang berasal dari ajaran Islam. Pekanbaru sebagai kota yang mengalami perkembangan pesat menerima dampak globalisasi. Hal ini karena, seperti kota-kota lain di Indonesia, kota ini memberikan "imajinasi" atau "mimpi" bagi kaum muda Muslim. Di Pekanbaru, anak muda Muslim dapat berinteraksi dengan media global melalui internet dan televisi. Namun, mereka juga diberikan penanaman nilai-nilai Islam yang berdampingan dengan media global. Nilai-nilai Islam ini sangat penting untuk mendukung agensi mereka ketika mengkonsumsi produk budaya asing akibat dari globalisasi.

Artikel ini pada dasarnya melanjutkan kajian di atas. Namun, berbeda dengan beberapa kajian di atas, artikel ini difokuskan pada dakwah anak muda di Kota Pekanbaru yang dilakukan oleh FSRMM (Forum Silaturrahim Remaja Masjid dan Mahasiswa).

\section{Metode}

Jenis dan pendekatan penelitian yang digunakan dalam penelitian ini yaitu deskriptif kualitatif, yaitu menggambarkan atau memaparkan secara sistematis, faktual dan akurat mengenai fenomenafenomena yang diangkat dalam penelitian, kemudian data-data tersebut dianalisis untuk memperoleh kesimpulan.

Teknik pengumpulan data artikel ini dilakukan dengan cara wawancara, observasi, dan dokumentasi. Wawancara ini dilakukan dengan tujuh informan di antaranya: Hajril Aswandi (Ketua FSRMM Forum Silahturrahim Remaja Masjid dan Mahasiswa), Reza Luthfi (Anggota tetap FSRMM di bidang dewan majlis syuro), Lintang Timur (Ketua Devisi Dakwah dan Kaderisasi), Fahrul (Ketua Devisi Perpus dan Inventarisi), Cahyo (Jamaah Tahsin FSRMM) dan Efri (Jamaah Halaqoh FSRMM).Yogi Praseyta (Ketua Devisi Humas dan Aksos). Observasi dilakukan dengan cara mengikuti setiap kegiatan dakwah yang dilakukan oleh FSRMM. Observasi dilakukan selama tiga bulan. Sementara dokumentasi digunakan untuk melihat program kerja, struktur organisasi dan hal-hal yang terkait dengan FSRMM.

\section{Hasil dan Pembahasan}

\section{Dakwah Bil- Lisan melalui Halaqoh dan Tahsin}

Aktivitas Dakwah bil-lisan adalah dakwah yang dilakukan melalui, lisan atau suara baik itu melalui Halaqoh dan tahsin ataupun Tabligh Akbar. Aktivitas dakwah di bidang bil-lisan ini da`i sangat penting dalam menyampaikan dakwah. Dakwah bil-lisan FSRMM terbagi dua Kegiatan yaitu Halaqoh dan Tahsin dan Tabligh Akbar di antaranya:

a.Halaqoh

Halaqoh merupakan kegiatan rutin yang dilakukan oleh FSRMM. Kegiatan ini dibagi menjadi dua kelompok, akhwan (laki-laki) dan akhwat (perempuan). Halaqoh ikhwan diadakan setiap minggu sekali, yaitu pada hari selasa (malam rabu) setelah ibadah sholat isya. Pemberi materi kegiatan 
adalah anggota FSRMM. Sistemnya bergiliran dan untuk tema da isi halaqohnya diberikan wewenang kepada pemberi materi. Sebenarnya halaqoh ini untuk pembelajaran, yang paling penting itu mengasah public speaking, menambah wawasan, dan mengasah mental, jadi itu tujuan dari halaqoh. Sedangkan untuk halaqoh yang Akhwat diagendakan setiap Juma at malam di kediaman Ustaz pemberi materi.

Hajril Aswandi yang mengatakan bahwa:

“Di FSRMM sendiri kami melakukan pembinaan tekhusus Remaja yaitu pembinaan melalui kepemimpinan, bekal ilmu, contoh nya itu kami memiliki program Halaqoh Rutin bersama Ustaz, di program halaqoh materi nya pun beragam yaitu fiqih, tasawuf, kemudian Akidah, dan tidak ketinggalan materi tentang Adab. Untuk Target kegiatan halaqoh ini salah satu nya Remaja tetapi kegiatan halaqoh ini terdapat juga Mahasiswa dan masyarakat umum. Tujuan halaqoh salah satunya adalah membangun Ukhuwah Islamiyah dan membangun mental teman-teman dalam menyampaikan dakwah salah satunya adalah pembinaan dalam membawa acara seperti MC, membaca AlQuran, dan mengisi materi secara begilir. Salah satu pengisi halaqoh kami yaitu khusus nya Anggota FSRMM sendiri dan kami membuka secara luas untuk teman-teman yang mau bergabung atau secara umum" (Hajril Aswandi, 2021)

Dakwah bil-lisan FSRMM yaitu Halaqoh Ikhwan yang dilaksanakan rutin, Dapat diartikan juga perngertian halaqoh ini adalah pertemuan keagamaan untuk mempelajari Islam dan Al-quran, secara umum dapat diartikan ada satu atau lebih pembicara utama yang menyajikan topik dan ditentukan dari halaqoh, sementara yang lain duduk disekitar mereka dan mendengarkan. FSRMM sebagai wadah dan pengembangan dakwah rutin mengadakan. Sistem halaqoh ikhwan ini diatur dengan posisi lingkaran yang sudah disiapkan oleh panitia halaqoh, peserta halaqoh terdiri dari berbagai macam latar belakang pendidikan dan pekerjaan ada yang berprofesi sebagai mahasiswa, pegawai negeri, dan masyarakat umum. Adapun sistem halaqoh ini yaitu terdiri dari pembawa acara, tartil, dan pemateri. Bukan hanya halaqoh ikhwan saja yang ada pada FSRMM ini tetapi ada halaqoh khusus akhwat yang diagendakan pada malam Jum`at via Zoom, sedangkan peniliti lebih berfokus kepada Halaqoh Ikhwan. Dengan kegiatan yang dibuat FSRMM seperti Halaqoh dan tahsin Majlis Syuro (Badan yang mengawasi kegiatan-kegiatan) tetap memantau kegiatankegiatan yang dibuat oleh setiap devisi-devisi FSRMM.

Peniliti juga mewawancarai satu orang peserta halaqoh yang hadir pada kegiatan halaqoh Ikhwan yaitu Efri (Mahasiswa UIN Suska Riau) yang mengikuti Halaqoh Ikhwan.

"saya tertarik mengikuti Halaqoh rutin ikhwan FSRMM, karena saya mendapatkan info dari anggota FSRMM bang Rian beliau mengirimkan poster kegiatan halaqoh rutin FSRMM jadi saya tertarik untuk mengikuti, sedangkan untuk materi yang diberikan di saat halaqoh cukup menarik, dan kita juga bisa mengecas iman dan juga bisa bergabung dengan pemuda-pemuda yang bersemangat mengikuti kegitan halaqoh tersebut. (Efri, 2021)

Materi halaqoh lainnya adalah Semangat Membaca dan menghafal Al-Qur`an. Materi ini diisi oleh Ustaz Angga dengan men terjermahkan dan memahami Surah Al-Fatir Ayat 29-30. Berdasarkan 
penjelasan Ustaz Angga Surah Al-Fatir memiliki makna ber tapa penting membaca Alquran dan mengamalkannya. selain itu, Ustaz Angga juga menambahkan bahwa membaca Alquran dapat menambah pahala. Lebih jauh, Ustaz Angga menjelaskan tentang kunci membaca Alquran yaitu sabar dan istiqomah.

Halaqoh adalah aset dalam tradisi Islam yang lahir, tumbuh dan berkembang dalam masyarakat Islam yang sudah tentu dasar, proses dan tujuannya t sesuai dengan sumber ajaran Islam dan karakter kebudayaan masyarakat Islam. Halaqoh adalah sebuah istilah yang ada hubungannya dengan dunia pendidikan, khususnya pendidikan atau pengajaran Islam (tarbiyah Islamiyah). Istilah Halaqoh (lingkaran) biasa digunakan untuk menggambarkan sekelompok kecil Muslim yang secara rutin mengkaji ajaran Islam. Jumlah peserta dalam kelompok kecil tersebut berkisar antara 3-12 orang. Halaqoh adalah sebuah metode pendidikan dan dakwah Islam yang dikenal sejak zaman Rasulullah hingga sekarang. Hanya saja halaqoh sekarang telah mengalami pengembangan atau perubahan. Halaqoh sebagai alat alternatif sistem dakwah dan pendidikan Islam yang cukup efektif untuk membentuk Muslim berkepribadian Islami.

Fenomena halaqoh menjadi umum dijumpai di masyarakat Muslim. Penyebaran halaqoh yang pesat tidak bisa dilepaskan dari motivasinya pendirinya untuk mendidik muslim yang bertaqwa kepada Allah SWT. Pada saat ini halaqoh menjadi sebuah alternatif pendidikan keislaman yang masif dan merakyat. Tanpa melihat latar belakang pendidikan, ekonomi, sosial atau budaya pesertanya. Bahkan tanpa melihat apakah seseorang yang ingin mengikuti halaqoh tersebut memiliki latar belakang pendidikan agama Islam atau tidak. Halaqoh telah menjadi sebuah wadah pendidikan Islam (Tarbiyah Islamiyah) yang semakin inklusif saat ini.

Menurut Ali Imran dengan mengutip pendapat Muhammad Natsir adalah dalam pelaksanaan dakwah Islamiyah terjadi di dalamnya proses pendidikan yang tidak lepas dari da i dan muballigh sebagai Objek dakwah (sasaran dakwah) baik secara individu maupun orang banyak, serta lembaga dakwah, kedua nya adalah hal yang harus ada dalam proses tarbiyah, meliputi:Tabligh,(dakwah secara umum) sebagai alat propaganda, Da`wah fardiyah,(pendekatan personal) sebagai sarana pemilihan sasaran (objek) dakwah untuk dibina Takwiniyah,(pembentukan) sebagai sarana pengkaderan agar menjadi seorang Muslim sejati yang memiliki dedikasi dan seamangat juang tinggi dalam mendakwahkan Islam. Tanfizhiyah (Pelaksanaan) sebagai ajang amal untuk berkiprah dalam dunia dakwah.

Selain program halaqoh, FSRMM juga mengadakan program Tahsin Al-Qur`an yang diagendakan pada Sabtu setelah Ba`da Ashar, untuk kelas dasar itu dibimbing oleh Hajril Aswandi dan Nanda, di kelas dasar ini mengajarkan hukum tajwid, Makhrojatul huruf, dan ketepatan dan kelancaran membaca Al-Qur`an. Sedangkan Tahsin Akhwat diagendakan pada hari Kamis setelah Ba`da Ashar Via Zoom.

Tahsin juga menjadi bagian dari dakwah bil lisan. FSRMM melakukan tahsin dua minggu sekali setiap hari kamis dan sabtu. Hal ini disampaikan oleh Hazril, selaku pembimbing tahsin.

"Kami membuat program Tahsin ini tujuannya adalah ingin membantu teman-teman yang ingin memperbaiki bacaan salah satu nya mendalami Hukum Tajwid, Makhrojatul Huruf, dan ketepatan huruf yang dibaca, kami juga membuka kelas dasar untuk teman-teman yang baru 
pemula untuk belajar Tahsin Alquran. Kegiatan Tahsin ini juga kami buka dengan secara Gratis tanpa di pungut biaya apapun.

Hal senada juga disampaikan oleh Tengku Ramadhan sebagai Anggota FSRMM yang mengatakan bahwa

"Alhamdulillah saya sudah bergabung di Tahsin FSRMM ini sudah satu tahun, saya masuk tahsin FSRMM ini karena saya mengikuti instagramnya FSRMM dan pada saat itu ada flayer atau poster yang membuka kelas tahsin dan saya langsung ikut mendaftarkan diri sebagai perserta tahsin itu. metode belajar di program tahsin ini adalah yang paling utama yaitu Ustaz mentalqin atau Ustaz dulu yang membacakan Surah tersebut selanjutnya kami mengikuti apa yang telah dibacakan oleh Ustaz tersebut. untuk perubahan selama saya bergabung ditahsin FSRMM ini sangaat bagus sekali karena awalnya saya berpikiran bahwasanya Alfatihah saya itu sudah bagus tetapi setelah saya mengikuti program tahsin tersebut banyak kesalahan dalam pengucapan baik pengucapan dari ayat-ayat tersebut. tujuan saya mengikuti program tahsin ini salah satunya adalah memperbaiki bacaan Alquran namun dengan beriring jalan nya waktu teman-teman di FSRMM juga welcome kepada saya dan saya juga ingin menjaga diri sebagai generasi muda yang memiliki tantangan yang sangat besar jadi saya selalu mengikuti kegiatan-kegiatan yang dilaksanakan FSRMM sendiri. (Tengku Ramadhan, 2021)

Peneliti juga mewawancarai Peserta Tahsin yang telah bergabung pada tahun 2020, peneliti juga menanyakan kepada informan terkait anak muda bergabung dengan kegiatan tahsin?

"Saya masuk pendaftaran Tahsin pada awal tanggal 12-15 Agustus 2020, setelah itu saya mengikuti test bacaaan tanggal 16 Agustus 2020 untuk menentukan kelas lanjutan atau kelas dasarnya. Saya mengenal kegiatan tahsin ini berawal dari teman saya yang mengikuti kajian FSRMM dan saya juga mengikuti Instagram mereka dan Alhamdulillah saya sekarang mengikuti Tahsin di FSRMM. Saya sangat tertarik sekali dengan program yang buat oleh FSRMM tentunya kegiatan fsrmm memberikan hal positif terkait ilmu dan pengetahuan tentang agama sehingga bisa menambah wawasan yang baik." (Cahyo, 2021)

Selain Halaqoh Program dakwah FSRMM juga melaksanakan kegiatan Tahsin Alquran. Menurut Della dan Fitroh Hayati dengan mengutip pendapat Abdur Rauf adalah Tahsin adalah salah satu cara untuk tilawah Alquran yang menitikberatkan pada makhroj (tempat keluarnya huruf), sifat-sifat huruf dan ilmu tajwid. Metode ini melalui talaqqi (bertemu langsung) dan musyafahah (pembetulan bibir saat membaca) berhadapan langsung dengan guru atau syaikh yang sanadnya bersambung sampai kepada Rasulullah. Di dalam program tahsin FSRMM menekankan kepada aspek hukum tajwid ini berguna untuk memperbaiki bacaan anggotanya. Hal ini sesuai dengan urgensi metode tahsin menurut Della dan Fitroh hayati yang mengatakan bahwa urgensi metode tahsin ada empat yaitu: pertama, memperbaiki bacaaan yang baik dan benar, kedua, memudahkan dalam memahami isi Alquran, ketiga, mendapatkan pahala dari Allah SWT, keempat, mengajarkan orang lain. (Della Indah Fitriani, Fitroh Hayati, 2020: 17-18) 


\section{Tabligh Akbar}

Tabligh Akbar FSRMM diagendakan satu Bulan terakhir setiap Malam minggu yang merupakan agenda bulanan FSRMM, Adapun pengisi ceramah Tabligh Akbar yaitu dengan cara bergilir setiap bulannya antara lain Ustaz Syamsurizal, Ustaz Muhammad Hanafi, Ustaz Doni putra, Ustaz Rifki. Adapun Tema Tabligh Akbar FSRMM yang menarik yaitu "Pengen Jadi Baik" Sesuai wawancara peneliti dengan Hajril Aswandi Ketua FSRMM.

"Sebetulnya Pengen Jadi Baik itu adalah tajuk judul nya saja tujuannya adalah agar menarik minat Anak muda untuk menegakkan dakwah itu semakin kuat, jadi kalau seandainya tema nya di buat Tabligh Akbar saya rasa sangat formal sekali. Maka dari itu kami buat tema nya menarik mungkin yaitu "Pengen Jadi Baik" (Hajril Aswandi, 2021)

Selain Tema yang menarik Tabligh Akbar ini sudah dilaksanakan pada Awal bulan Januari dan Bulan Februari, pada Januari sendiri Judul nya yaitu "READY" yaitu artinya apakah kita siap menghadapi fenomena-fenomena alam yang terjadi seperti banjir, Tsunami dan seterusnya, sedangkan pada bulan Februari Tabligh Akbar yang diadakan di Masjid Al-Ikhlas Jl. Paus dengan Judul "Teruntuk Hati" yaitu membahas tentang bagaimana cara menjaga hati agar lebih baik, seperti gambar 1 .

Tabligh akbar tersebut secara masif dipromosikan melalui media sosial seperti Story Whatshapp, Instagram, dan Youtube, promosi tabligh akbar di media sosial tersebut mendapatkan respon dari warganet. Sebagian mengapresiasi acara tersebut. Peneliti juga menghadiri Tabligh Akbar yang diadakan di Masjid Al-Ikhlas Jl. Paus. Pemateri pada Tabligh Akbar tersebut adalah Ustaz Muhammad Hanafi Lc, Msy dengan Tema Pengen Jadi Baik dan judul Tabligh Akbar nya "Hati". Dari penjelasan Tabligh Akbar tersebut Ustaz Muhammad Hanafi menjelaskan tema tentang hati yang dikutip dari kitab "Nasoih Addaniyah" Karya Abdullah Alhaddad. Menurut nya Qolbun memiliki arti Hati yang selalu berbolak balik sesuai dengan doa "Ya muqollibal qulub tsabbit qolbi 'alaa diinik (Wahai Dzat yang Maha Membolak-balikkan hati, teguhkanlah hatiku di atas agama-Mu)." Lebih jauh, Ustaz Hanafi menganjurkan kepada Jama`ah yang hadir agar mengamalkan doa tersebut setelah Sholat Maghrib dan Sholat Shubuh. Ustaz Hanafi juga membangun Argumentasi nya melalui hadist Nabi yaitu: "Ingatlah bahwa di dalam jasad itu ada segumpal daging. Jika ia baik, maka baik pula seluruh jasad. Jika ia rusak, maka rusak pula seluruh jasad. Ketahuilah bahwa ia adalah hati (jantung)" (HR. Bukhari no. 52 dan Muslim no. 1599). 


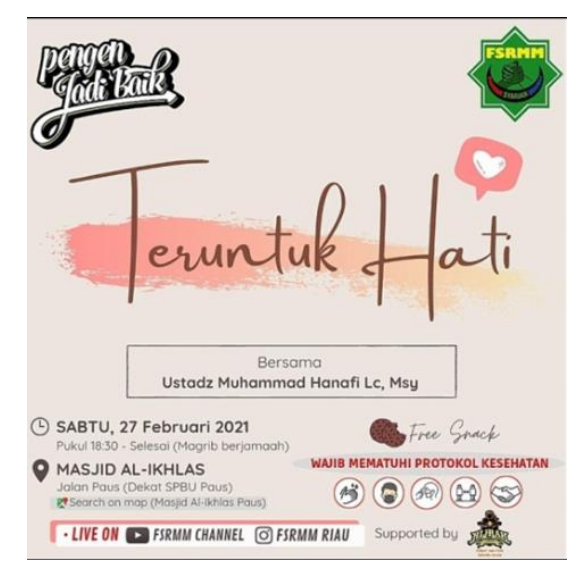

Gambar 1: Tabligh Akbar "Teruntuk Hati"

Tabligh adalah bagian dari sistem dakwah Islam. Kegiatan dakwah adalah usaha bersama orang yang beriman dalam merealisasikan ajaran Islam kedalam seluruh aspek kehidupan yang dilakukan melalui lembaga-lembaga atau organisasi-organisasi, Sedangkan Tabligh adalah usaha menyampaikan dan menyiarkan pesan Islam yang dilakukan oleh individu maupun kelompok baik secara lisan maupun tulisan. Secara konseptual, Tabligh identic dengan dakwah, bahkan dalam AlQuran suran Al-Maidah Ayat 67 memberikan maksud yang sangat gamblang dan komphenrensif bahwa, kata-kata Tabligh melalui ayat tersebut diantaranya merupakan penugasan tentang keberadaan Risalah Nabi Muhammad SAW, dimana risalah tersebut bersumber dari Al-Quran dan sunnah apabila tidak disampaikan kepada orang banyak maka berarti risalah itu gagal total. Dari pengertian di atas pengertian Tabligh sama hal dengan arti Tabligh akbar yang di laksnakan oleh FSRMM.

Tabligh Akbar FSRMM telah memenuhi unsur-unsur dakwah. Unsur-unsur dakwah adalah komponen-komponen yang terdapat dalam setiap kegiatan dakwah. Unsur-unsur tersebut adalah da`i (pelaku dakwah) atau (mitra dakwah), maddah (materi dakwah), wasilah (media dakwah), thariqah (metode), dan atsar (efek dakwah). (Moh. Ali Aziz, 2004: 61-63)

\section{Dakwah di Youtube dan Video Instagram}

Sesuai dengan penelitian peneliti mengenai dakwah FSRMM yaitu melalui Youtube, dan Video Instagram. Peneliti sedikit memberikan penjelasan tentang Youtube dan Video Instagram di bawah ini. Sejak berdirinya FSRMM Pada tahun 2009 mereka telah menggunakan media sosial untuk melakukan dakwah di kalangan dakwah anak muda di Kota Pekanbaru. Beberapa media sosial yang mereka gunakan yaitu seperti Youtube, (FSRMMTV), Facebook (FSRMMTV), dan Instgram (@fsrmmriau). Hal ini sesuai dengan hasil wawancara dengan Hajril Aswandi Ketua FSRMM.

"Kalau ditanya adanya dakwah media ini seperti Youtube, Instagram, Faceboook, itu sudah sejak lama dari pertama FSRMM terbentuk, sudah ada dakwah media pada tahun 2009, dikarenakan pada masa pandemi ini juga fsrmm sendiri makin gencar dalam menyampaikan dakwah media seperti Story Whatsapp, Instagram, Facebook”(Hajril Aswandi, 2021) 
Akun Youtube FSRMMTV, sampai pada tanggal 24 Februari 2021 telah mengunggah 571 video dengan jumlah subscriber mencapai 841 ribu. Konten-konten dakwah yang mereka unggah meliputi sejumlah kajian-kajian keagamaan yang diisi oleh Ustaz-ustaz di Pekanbaru dan Nasional seperti Ustaz Abdul Somad, Ustaz Zulkifli, Ustaz Yahya Walni, Ustaz Alnof Dinar, Ustaz Muhammad Hanafi, Ustaz Salim A Fillah, dan lainnya. Meskipun demikian, sejauh pengamatan peneliti di akun Youtube FSRMMTV video yang banyak diupload adalah video dakwah Ustaz Abdul Somad untuk menyebutkan beberapa contoh, FSRMM mengunggah video tentang "Manfaat Sedekah, Rezeki atau Laknat". "Kupas Tuntas Seputar Qurban", dan "Tanya Jawab Seputar Agama".

Seperti halnya dakwah di Youtube, dakwah yang dilakukan FSRMM di Facebook juga banyak mengunggah video kajian-kajian dakwah yang di isi oleh sejumlah Ustaz yang telah disebutkan di atas seperti video tentang "Perempuan bisa bekarya", "Ceramah NonStop 1,5 Jam Desa Kuntu", "Satu Jam Bedah Buku Bersama Ustaz Abdul Somad 2020 Jambi Buku Tuan Guru Nadjmi” dan "Untuk Apa Sholat". Video-video tersebut merupakan hasil Live Streaming ceramah Ustaz Abdul Somad di sejumlah tempat. Selain mengunggah hasil Live Streaming, FSRMM juga mere-posting (memposting ulang) unggahan akun facebok lain. Sebagai contohnya, FSRMM mengunggah video dakwah Ustaz Abdul Somad berjudul "Kajian Kitab Fathul Mubin" yang telah lebih dahulu diposting oleh akun @Sahabatuasofficial. Jam tayang Ustaz Abdul Somad Selama Ramadhan seperti Gambar 2. Sampai tanggal 24 Februari 2021 Akun Facebook fsrmm telah memperoleh 519 like dan pengikutnya.

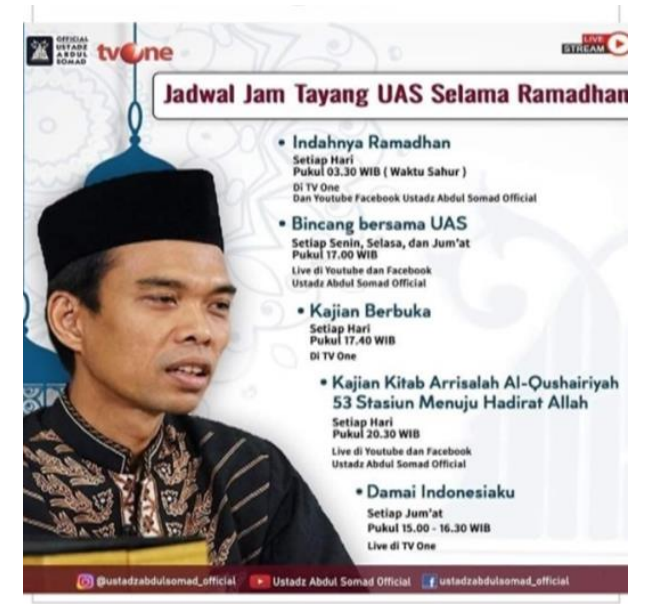

Gambar 2: Jadwal Tayang UAS selama Ramadhan

Beberapa video terpopuler dari Akun Youtube FSRMMTV yaitu pertama video yang berjudul ceramah lucu Ustaz Abdul Somad di Masjid Al-Muhajirin Desa Laboi Jaya Bangkinang, Kedua, Ceramah Full Ilmu Stress Pun Hilang di Mesjid Pagerageung, Ketiga, Ceramah Ustaz Abdul Somad Tentang Manfaat Shodaqoh di Masjid Al-Makmur Pekanbaru (Dalam Rangka Membangun 
Masjid). Pada video pertama Ustaz Abdul Somad menjelaskan tentang keutamaan sholat. Untuk menjelaskan keutamaan sholat tersebut UAS mengutip dan menjabarkan dari surat Al-Kautsar. Video ini ditonton 10,087,862 views, dan like nya sebanyak 61 ribu dan dislike 7.1 ribu. Di ruang komentar netizen banyak memberikan komentar positif didalam video tersebut. Salah satu komentar positif dari netizen yang berasal dari Malaysia yaitu Azura Fadzli yang mengatakan "Salam dari Malaysia untuk mu Indonesia Saya peminat Ustaz Abdul Somad".

Video yang kedua menjelaskan tentang Kerbekahan Sholawat kepada Nabi Muhammad SAW, video ini di tonton sebanyak 2,284,251 views dengan like 35 ribu dan dislike 2.7 ribu. Di ruang komentar netizen banyak memberikan komentar positif juga terhadap video UAS, Salah satu komentar netizen Azhar Kusuma" Semoga di panjangkan umur Ustz Abdul Somad, selalu menjadi Ustaz yang istqomah dalam menegakkan Agama Allah amin" Selanjutnya video ketiga menjelaskan pentingnya bershodaqoh di jalan Allah dengan cara berinfaq dalam membangun masjid, video ini di tonton 1,576,989 views, dan like 13 ribu dan dislike 1.7 ribu. Sama halnya di ruang komentar netizen yang berasal dari negara Singapore yaitu Rumini Rukin "singapore hadir menyimak, alhamdulillah bisa selalu mendapatkan ilmu dari ustad abdul somad, sehat selalu ustad".

Youtube dalam praktiknya mampu memberikan ruang tersendiri bagi para penggunanya, lebih lanjut, Youtube mampu menjadikan ruang publik yang memfasilitasi para pengguna untuk dapat berkomunikasi dan saling bertukar pendapat. Tak terkecuali, banyaknya spekulasi dan argumen yang saling dipertukarkan turut menjadi bagian dan arus informasi yang tercipta pada ruang public melalui Youtube, hal ini juga terjadi dalam konteks keberagamaan Indonesia. Salah satu Implikasi penggunaan Youtube untuk sarana dakwah juga berkenaan dengan kecenderungan dari para pengguna Youtube, khususnya pengguna media sosial. Dalam mengakses sejumlah konten dakwah. Implikasi penting dalam hal ini muncul bagi sebagaian besar masyarakat Muslim Kontemporer di Indonesia, yakni dengan memanfaatkan Youtube sebagai media pembelajaran Islam. Tren yang muncul mampu memberikan sumber rujukan atas pengetahuan keagamaan yang ingin diperoleh bagi sejumlah penggunanya. Menurut Ferdi Arifin dalam Horsfield (2018) menjelaskan adannya sisi kompleks dalam memaparkan praktik keagamaan yang menuntut cara agama untuk dapat memainkan peran fungsionalnya untuk melayani umat, khususnya dalam konteks komunitas, ritual, serta upaya dalam menemukan ideologi makna. Maka dari itu, kemunculan media baru diperlukan guna menawarkan sebuah pendekatan fungsional dalam melihat tentang cara studi agama mampu merujuk pada pandangan mengenai aspek keagaman yang baru. (Ferdi Arifin, 2019: 93-96).

Penggunaan Youtube di dalam internet merujuk ke dalam keagamaan yang memiliki hubungan antara penggunaan media lama dengan media baru secara bersamaan. Menurut Ferdi Arifin dalam Campbell dan Lovheim (2011) menyatakan bahwa praktik keagamaan online sebenarnya tidak dapat berdiri sendiri tanpa praktik offline sehingga, masing-masing akan saling mempengaruhi, pernyataan selanjutnya ada juga kecendrungan dari religiositas yang dilakukan secara offline. Adapun penggunaan fasilitas dan media online sebagai sarana dakwah dapat dikatakan sebagai pengembangan dalam strategi lama guna memobilisasi khalayak secara lebih 
cepat. Para pengguna Youtube atau sering disebut Youtuber, bisa menghasilkan pundi-pundi rupiah jika memenuhi kriteria yang ditentukan oleh pihak Youtube, seperti like, subscribe, dan share.

Pada dasarnya, berdakwah dengan memanfaatkan internet dan media sosial memberikan dampak tersendiri bagi para penggunanya. Dalam konteks ini, perlu adanya perencanaannya untuk dapat mengemas konten dakwah yang sesuai dan diminati oleh para audiens. Salah satu tujuan utama berdakwah di Youtube adalah menarik minat dan memberikan kemudahan khalayak untuk mempelajari ajaran keIslaman. Namun, tak jarang terjadi perbedaan pendapat terhadap ustaz terkait pemahaman keIslaman yang dimiliki. Perbedaan tersebut mampu menimbulkan perdebatan pada masing-masing kolom komentar youtube yang digunakan. Berdakwah di media sosial dianggap semakin banyak diminati karena dinilai lebih efektif dan efisien. Akan tetapi, hal ini yang justru memunculkan tantangan tersendiri. Salah satu bentuk tantangan tersebut adalah terdapat fitur monetiasi yang dapat dilakukan dalam penggunaan media sosial Youtube.

Selain pesatnya dakwah bil-lisan dengan Youtube terdapat dakwah simple yaitu dakwah dengan Instagram yaitu dengan memposting video-video dakwah, Instagram sendiri berasal dari insta dan gram, “ insta yang berasal dari kata instant dan gram berasal dari Telegram, dapat diartikan Instagram merupakan media komunikasi yang menginformasikan berupa foto atau gambar secara cepat lewat aplikasi yang dapat diakses oleh orang lain. (Nurul Avifah, 2017: 227228).

Penggunaan Internet dengan Youtube dalam berdakwah telah dimungkinkan, sangat penting dan sangat strategis dalam masyarakat informasi. Salah satu nya Internet telah mengubah cara komunkasi dengan cara yang sangat mendasar, terutama melibatkan banyak interaktivitas antara komunikator dengan pengguna. Melalui Internet juga kegiatan dakwah dapat terlaksana dengan menyertakan jutaan orang di seluruh dunia, tanpa adanya hubungan yang bersifat pribadi. Pada saat pertama kali Internet diperkenalkan oleh para ilmuan barat, hamper dari kebanyakan tokoh Islam merasa curiga dan khawatir akan efek dari temuan teknologi tersebut.

Menurut Muhammad Sa id Ramadhan al-Buthi dakwah melalui Internet sangat efektif dan potensial terdapat empat penjelasan yaitu Pertama,mampu menembus batas ruang waktu dalam sekejab dengan biaya dan energy yang relative terjangkau, Kedua, pengguna jasa internet setiap tahunnya meningkat drastic, ini berarti sangat berpengaruh pula pada jumlah penyerap misi dakwah. Ketiga, para pakar dan ulama yang berada dibalik media dakwah via internet bias lebih kosentrasi dalam menyikapi setiap wacana dan peristiwa yang terjadi. Keempat, dakwah melalui internet telah menjadi salah satu pilihan masyarakat. (Toni Hartono dkk, 2011: 137-139). Selain Youtube dan Facebook, FSRMM juga melakukaan dakwah dengan video instagram, di instagram FSRMM juga mengunggah berbagai video dakwah mereka seperti kegiatan Halaqoh Rutin, Touring Bareng Ustaz Abdul Somad, dan video dakwah singkat tentang nesehat dari Ustaz Abdul Somad, video ajakan untuk membaca dan mengamalkan Surah Al-Kahfi, dan lainnya.

Media video dapat diklafikasikan sebagai media Audio Visual. Media ini juga dapat menampilkan unsur gambar (Visual) dan suara (Audio) secara bersamaan pada saat mengkomunikasikan pesan dan informasi kepada khalayak. Walaupun bentuk fisiknya berbeda, 
media ini banyak memiliki kesamaan dengan media film. Keduanya dapat menayangkan unsur gerak. (Amin, 2013: 122) Video tepat sekali digunakan untuk kepentingan dakwah, terlebih lagi memancarkan program dalam bentuk Audio Visual. Terlebih lagi, program video dapat di susun sesuai selera da`i dan dapat disiarkan sesuai dengan kebutuhan tanpa harus bergantung pada stasuin pusat.

Media video juga dapat mengungkapkan objek dan keadaan peristwa yang sesunggunya. Perancanaannya yang baik oleh seorang da i dalam menggunakan media ini akan membuat proses komunikasi pesan dan informasi dakwah menjadi efektif dan mudah diterima. Saat ini, media video sudah banyak digunakan oleh para da i menyampaikan pesan dakwah. Salah satu contoh aplikasi media sosial yang tengah hangat dikalangan masyarakat khususnya Anak muda adalah Instagram. Innstagram merupakan aplikasi yang dirancang untuk mentransformasikan foto, video, fiter dan dilengkapi dengan akses untuk saling berbagi foto dengan aplikasi media sosial lainnya. Lewat-lewat fitur instagram dapat dimanfaatkan oleh masyarakat untuk mengunggah foto dan video mereka. Dengan demikian, pergerakan da`wah perlahan akan dikenal oleh pengguna Instagraman diharapkan memberikan nilai-nilai kebaikan. Salah satu contoh kelompok anak muda yang memanfaatkan instagram sebagai ladang da`wah adalah kelompok pemuda hijrah. Kelompok anak muda ini aktif menggunakan instagram untuk menyampaikan dak wah Islam lewat konten foto, caption, video pendek dan informasi seputar kajian Islam. (Fathayatul Husna, 2020: 1)

\section{Poster Dakwah}

Selain Youtube dan Facebook sebagai alat media dakwah FSRMM juga meliputi Poster-poster dakwah antara lain seperti kata-kata nabi dan tokoh agama serta hadist nabi seperti gambar 3 di bawah ini.

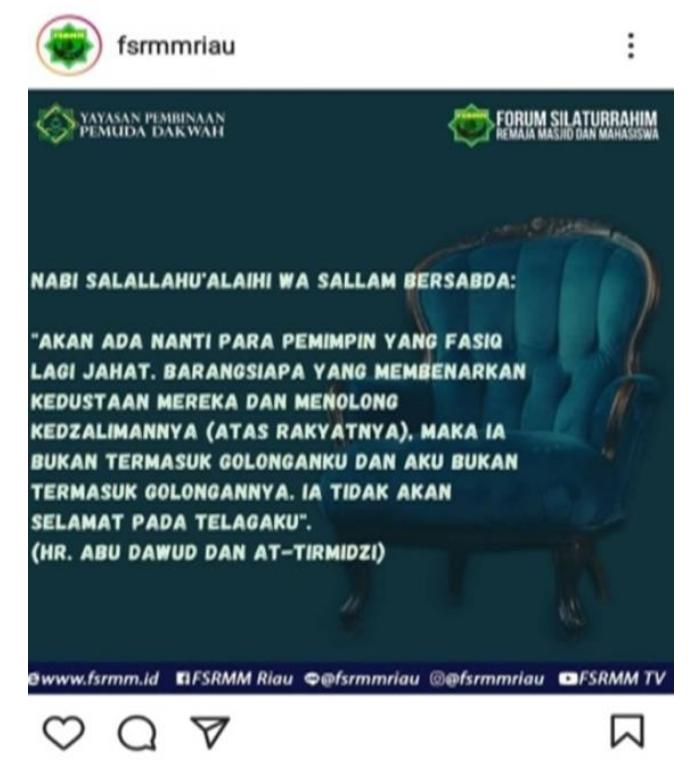

Gambar 3: Poster Hadist Nabi tentang Kepemimpinan 
FSRMM juga mengupload Poster Hadist Nabi yang menjelaskan tentang perumpamaan orang menginfakkan hartanya dalam bersedekah, di dalam penjelasan Poster itu adalah Allah akan menjadikan sebutir biji yang menjadi tujuh tangkai, dan pada tiap tangkai ada seratus biji, dan Allah melipatgandakan bagi siapa yang Dia kehendaki. Sesuai dengan wawancara peneliti kepada Hajril Aswandi Ketua FSRMM.

"Dengan dakwah lewat Media ini kami bisa mengajak dan menyeru kebaikan dengan memposting Poster atau pengingat di Laman Instagram kami, Dan bukan hanya itu saja orang lain bisa melihat postingan-postingan dakwah kami yang inyaallah bermanfaaat untuk semua" (Hajril Aswandi, 2021)

Selain Poster dakwah Hadist Nabi, FSRMM mengunggah Poster dakwah tentang Sedekah, Ibadah, dan lainnya. Setiap hari Jum`at Poster tentang memperbanyak membaca Surah Al-Kahfi dan mengamalkannya. Dakwah Bil-Qalam adalah dakwah yang dilakukan melalui tulisan-tulisan seperti di Surat-surat kabar, majalah, Buku, maupun internet. Dalam metode dakwah Bil-Qalam ini tidak hanya diperlukan pandai menulis namun juga pandai dalam menyusun kata-kata sehingga menjadi kalimat yang indah, tidak banyak orang yang biasa berdakwah dengan metode ini dikarenakan perlunya kemampuan khusus untuk mengaplikasikannya. (Muhammad, 1994: 332).

Pengertian Dakwah Bil-Qalam dapat di artikan menurut Bahasa, yaitu bahasa Arab, Dakwah Bil-Qalam jika ditulis sesuai gramatikal bahasa arab, maka akan di tulis ad-da`wah bi-al-qalam, terdiri dari dua kata yaitu, da`wah dan qalam. Dakwah Bil-Qalam yaitu upaya menyeru manusia menggunakan cara yang bijaksana kepada jalan yang benar sesuai perintah Allah SWT melalui seni tulisan. Pengertian dakwah bil-qalam menurut Suf Kasman yang dikutip Tafsir Departemen Agama RI menjelaskan definisi dakwah Bil-Qalam, ialah menyeru manusia secara bijaksana dan dijalan yang benar sesuai perintah Allah SWT. Dakwah Bil-Qalam telah diaplikasikan pada zaman Rasulullah, karena pada saat itu, tradisi tulis-menulis sudah berkembang, terbukti ketika Rasulullah SAW menerima wahyu yang diterima nya, padahal pada zaman itu secara teknis sangat lemah untuk bias melaksanakan kegiatan tulis-menulis dikarenakan sarana yang belum tersedia seperti kertas dan alat tulis lainnya. Di samping budaya yang kurang mendukung namun para sahabat tetap berusaha untuk mampu melakukannya.

Salah satu contoh dakwah bil-qalam ini adalah poster, Poster adalah karya seni atau desain grafis yang memuat komposisi gambar dan huruf di atas kertas berukuran besar. Salah satu bentuk poster yang bisa digunakan sebagai sarana dakwah adalah poster propaganda. Poster ini juga dimanfaatkan sebagai ajakan untuk berbuat kebajikan dan mencegah kemungkaran melalui kalimat dan ilustrasi yang bernuansa Islami, seperti kata-kata, kalimat atau gambar yang bersumber pada Al-Quran dan hadist. Poster dakwah yang berisi kalimat-kalimat dan gambar yang bernuansa Islami yang dikembangkan untuk menjawab tantangan dakwah masa kini.

Muslim Designer Community (MDC) adalah satu kelompok komunitas designer Muslim di Indonesia yang membuat poster-poster bernuansa Islami. Komunitas ini terbentuk tahun 2013, berpusat di Gonilan, komunitas ini juga bertujuan untuk menyampaikan nilai-nilai dakwah yang tidak selamanya harus melalui ceramah, karena karya visual pun bisa berbicara dakwah. Lewat 
sajian poster-poster dan muatan-muatan isi yang menarik dan kreatif namun tetap juga menarik dan kreatif namun tetap memegang landasan Quran dan Sunnah. Salah satu dakwah bil-qalam diatas sesuai dengan program yang dilaksanakan FSRMM yaitu membuat Poster Dakwah di media Instagram yang berisikan informasi-informasi tentang Hadist nabi, dan kata-kata mutiara Islami.(Nilnan Ni mah, 2016: 110-111)

\section{Dakwah melalui Aksi Sosial}

Dakwah FSRMM tidak hanya dalam bentuk kajian-kajian keagamaan tetapi juga melalui aksiaksi sosial. Terkait dakwah melaui aksi sosial ini, FSRMM sebagian besar melakukan kerja sama dengan lembaga dakwah lain. Sebagai contohnya, dalam melakukan aksi sosial di Panti Asuhan Putri Ladang Amal dan Panti Asuhan Ar-rahman, FSRMM berkerja sama dengan Yayasan Pembinaan Pemuda Dakwah. Kegiatan aksi sosial tersebut diantaranya: Memberikan sembako, memberikan baju layak pakai, memberikan masker. Dalam aksi sosial lainnya FSRMM bekerja sama dengan Ustaz Abdul Somad, Tabung Wakaf Umat, Bank Riau Kepri dalam aksi sosial SPBU (Sedekah Pangan Bersama UAS). Aksi sosial ini bertujuan untuk meringankan bebas masyarakat dengan memberikan beras secara gratis kepada yang membutuhkan yang ada di seluruh penjuru kota Pekanbaru. Selain terlibat aksi sosial di wilayah lokal Pekanbaru, FSRMM juga ikut dalam menghimpun dan menyalurkan donasi di kota-kota lainnya bahkan luar negeri. Sebagai contohnya, FSRMM ikut merespon korban bencana gempa bumi Lombok Nusa Tenggara Barat, Korban Palestina, Suriah dan Rohingya. Dalam mengumpulkan donasi FSRMM dalam satu kasus mempromosikan Hadist Nabi yang mengatakan: "Perumpamaan orang Islam yang paling mengasihi dan mencintai satu sama lain adalah ibarat satu tubuh, jika salah satu anggota tubuh merasa sakit, maka seluruh tubuh akan ikut merasa sakit dan tidak bisa tidur". (H. R Bukhari). Dalam bulan Ramadhan FSRMM juga melakukan aksi sosial seperti berbagai takjil, Buka Puasa bersama Dhuafa, Lebaran Berkah (LB). Yogi Prasetya selaku Ketua Devisi Humas dan Aksos mengatakan bahwa aksi sosial yang dilakukan oleh FSRMM adalah:

"Di dalam masa jabatan saya selama dua bulan di FSRMM dan saya di amanahkan menjadi ketua Devisi Humas dan Aksos, kami membuat kegiatan Aksi sosial yaitu berupa bantuan sosial terhadap korban bencana Gempa Bumi di Palu, Sulawesi Barat, dan Banjir di Kalimantan Selatan. Selain itu pada Bulan Ramadhan yang lalu bertepatan pada bulan Mei 2020 kami melakukan Open Donasi terhadap masyarakat kurang mampu yang ada di pekanbaru, selain itu kami melakukan Bantuan Sembako terhadap masyarakat yang di PHK akibat dampak pandemi dengan bantuan sebanyak 30 paket dari 33 KK. Setelah itu kami bukan hanya memberi bantuan pada bulan Ramadhan saja tetapi kami membuka kembali Open Donasi untuk Bantuan Sembako dengan Tema "Lebaran Berkah" dengan Budget 300.000 ribu dari $10 \mathrm{KK}$. Insyaallah pada Bulan ini kami akan berencana untuk membuka Open Donasi kembali terhadap Kaum Dhuafa dengan Tema "SEBERAPA" (Sedekah Berupa Pangan). Kami juga mempromosikan kegiatan Aksi sosial ini dengan menyebarkan informasi berupa gambar open donasi terhadap korban bencana dan bantuan terhadap masyarakat yang 
membutuhkan dengan cara memposting gambar tersebut ke Instagram FSRMM dan kontak anggota internal FSRMM. (Yogi Prasetya, 2021).

Dakwah melalui aksi sosial ini secara normatif bisa dikaitkan dengan istilah dakwah bil-hal. Dakwah Bil-Hal secara etimologi merupakan gabungan dari dua kata yaitu dakwah dan al-hal. Kata dakwah artinya menyeru, memanggil. Sedangkan kata al-Hal berarti keadaan. Jika dua kata tadi dihubungkan maka dakwah Bil-Hal mengandung arti "memanggil", menyeru dengan menggunakan keadaan, atau menyeru, mengajak dengan perbuatan nyata". Dakwah Bil-Hal adalah dakwah dengan perbuatan nyata seperti yang dilakukan oleh Rasulullah Saw, terbukti bahwa pertama kali tiba di madinah yang dilakukan adalah pembangunan masjid Quba, mempersatukan Kaum Anshar dan Muhajirin dalam ikatan Ukhuwah Islamiyah.(Siti Muru`ah, 2000: 75). Dakwah Bil-Hal merupakan aktivitas dakwah Islam yang dilakukan dengan tindakan nyata atau amal nyata terhadap kebutuhan peristiwa dakwah. Sehingga tindakan nyata tersebut sesuai dengan apa yang dibutuhkan oleh penerima dakwah. (Munir, 2009: 178).

Berdasarkan penjelasan tentang Aktivitas Dakwah Di Kalangan Anak Muda di Kota Pekanbaru Studi Pada Komunitas FSRMM (Forum Silaturrahim Remaja Masjid Dan Mahasiswa) bahwasanya: Pertama, Dakwah Bil-Lisan di antaranya adalah Halaqoh dan Tahsin, Tabligh Akbar, Youtube dan Video Instagram. Halaqoh dan tahsin di FSRMM di lakukan di Sekretariat FSRMM, halaqoh dilakukan dengan cara membuat lingkaran yang dihadiri oleh anak muda Muslim pekanbaru dan langsung dibimbing oleh pemateri halaqoh sebagai narasumber di dalam halaqoh tersebut. Selanjutnya dakwah Bil-Lisan dalam bentuk tahsin. FSRMM melakukan Tahsin dengan cara Ustaz membacakan terlebih dahulu setelah itu peserta tahsin mengulang bacaan yang di bacakan Ustaz. di dalam proses Tahsin Ustaz mengajarkan bagaimana cara membaca Alquran sesuai Tajwid yang benar, pengucapan Makhrojatul Huruf yang tepat dan ketepatan dalam membaca Alquran.

Selain Halaqoh dan Tahsin dakwah Bil-Lisan FSRMM dalam bentuk Tabligh Akbar. Tabligh Akbar FSRMM mengacu kepada beberapa tema yaitu READY dan Teruntuk Hati. Program Tabligh Akbar ini dilakukan setiap satu bulan terakhir pada malam minggu. Pengisi dalam program tabligh akbar FSRMM yaitu Ustaz Syamsurizal, Ustaz Muhammad Hanafi, Ustaz Doni putra, Ustaz Rifki. setelah itu FSRMM juga aktif di media sosial salah satu nya Youtube dan Video Instagram. Dakwah FSRMM melalui youtube dengan cara memposting ceramah Ustaz Abdul Somad salah satu Pembina FSRMM. Selain Youtube FSRMM juga aktif memposting video Instagram berupa video halaqoh dan video Touring bersama UAS. Selain video halaqoh dan touring FSRMM juga memposting ulang live streaming yang terdapat di Youtube dan Facebook.

\section{Simpulan}

Berdasarkan penjelasan tentang Aktivitas Dakwah Di Kalangan Anak Muda di Kota Pekanbaru Studi Pada Komunitas FSRMM (Forum Silaturrahim Remaja Masjid Dan Mahasiswa) bahwasanya: Pertama, Dakwah Bil-Lisan di antaranya adalah Halaqoh dan Tahsin, Tabligh Akbar, 
Youtube dan Video Instagram. Halaqoh dan tahsin di FSRMM di lakukan di Sekretariat FSRMM, halaqoh dilakukan dengan cara membuat lingkaran yang dihadiri oleh anak muda Muslim pekanbaru dan langsung dibimbing oleh pemateri halaqoh sebagai narasumber di dalam halaqoh tersebut. Selanjutnya dakwah Bil-Lisan dalam bentuk tahsin. FSRMM melakukan Tahsin dengan cara Ustaz membacakan terlebih dahulu setelah itu peserta tahsin mengulang bacaan yang di bacakan Ustaz. di dalam proses Tahsin Ustaz mengajarkan bagaimana cara membaca Alquran sesuai Tajwid yang benar, pengucapan Makhrojatul Huruf yang tepat dan ketepatan dalam membaca Alquran.

Selain Halaqoh dan Tahsin dakwah Bil-Lisan FSRMM dalam bentuk Tabligh Akbar. Tabligh Akbar FSRMM mengacu kepada beberapa tema yaitu READY dan Teruntuk Hati. Program Tabligh Akbar ini dilakukan setiap satu bulan terakhir pada malam minggu. Pengisi dalam program tabligh akbar FSRMM yaitu Ustaz Syamsurizal, Ustaz Muhammad Hanafi, Ustaz Doni putra, Ustaz Rifki. setelah itu FSRMM juga aktif di media sosial salah satu nya Youtube dan Video Instagram. Dakwah FSRMM melalui youtube dengan cara memposting ceramah Ustaz Abdul Somad salah satu Pembina FSRMM. Selain Youtube FSRMM juga aktif memposting video Instagram berupa video halaqoh dan video Touring bersama UAS. Selain video halaqoh dan touring FSRMM juga memposting ulang live streaming yang terdapat di Youtube dan Facebook. Kedua, Dakwah Bil-Qalam di antarannya adalah Poster dakwah. Poster dakwah ini aktif dilakukan di Instagram FSRMM yaitu poster tentang kata mutiara, Hadist Nabi, dan poster anjuran membaca Surat Al-Kahfi di hari Jum`at. Ketiga, Dakwah Bil-Hal diantaranya kegiatan Aksi Sosial. Aksi Sosial yaitu Bantuan Sosial terhadap korban bencana yaitu gempa bumi di Palu, banjir Sulawesi barat dan Kalimantan Tengah. Setelah itu FSRMM juga bekerja sama dengan berbagai lembagalembaga yaitu Wakaf Tabung Umat dan Dompet Dhuafa.Dari ketiga metode dakwah di atas, metode yang sangat berperan penting di FSRMM yaitu metode dakwah Bil-Lisan yaitu berfokus di media sosial salah satu nya Youtube dan Video Instagram.

\section{Referensi}

Amin, S.M. (2013). Ilmu Dakwah. Jakarta: Amzah.

Amran.A. (2012). Dakwah dan Perubahan Sosial. Hikmah: Jurnal Ilmu Dakwah dan Komunikasi Islam, 6 (1), 71-72.

Arifin, F. (2019). Mubaligh Youtube Dan Komodifikasi Konten Dakwah. Al-Balagh: Jurnal Dakwah dan Komunikasi. 4 (1), 93-96.

Asy-Syaukani, M.A.M. (1994). Fathu al-Qadir: Jami "Baina Fanni ar-riwayah Wa ad-Dirayah min Ilmin al-Tafsir Juz V. Beirut-Lebanon: Daral-al-Kutub al-Ilmiyah.

Avifah, N. (2017). Efektivitas Dakwah Islam Melalui Sosial Media Dakwah Instagram. Jurnal Raushan Fikr 6 (2), 227-228.

Aziz, M.A. (2004). Ilmu Dakwah, Jakarta: Kencana.

Fatoni, U \& Rais, A.N.(2018). Pengolalaan Kesan Da’i Dalam Kegiatan Dakwah Pemuda Hijrah. Jurnal Komunikasi dan Penyiaran Islam 12 (2), 211-222.

Fitriani, D.I. \& Fitroh, H. (2020). Penerapan Metode Tahsin untuk Meningkatkan Kemampuan Membaca Alquran Siswa Sekolah Menengah Atas, Jurnal Pendidikan Islam Indonesia, 5 (1), 15-30, . 
Hartono, T., Rosidi, I., Arwan, \& Masduki. (2011). Komunikasi Dakwah, Pekanbaru: Yayasan Pustaka Riau.

Hidayati, P., Alfikri \& Hidayat, R. (2020). Aktivitas Dakwah Komunitas Muslim Bikers Indonesia (KOMBI). Idarotuna: Jurnal Kajian Manajemen Dakwah, 2 (2), 75-92.

Husna, F. (2020). Pemuda Hijrah: Anak Muda dan Da`wah Online. Jurnal Penelitian Sosial Agama, 5 (1), 51-75 .

Mahmud, A., \& Halim, A. (1995). Dakwah Fardiyah: Metode Membentuk Pribadi Muslim, Jakarta : Gema Insani Press.

Munir, M. \& Ilahi, W. (2009) Manajemen Dakwah, Jakarta: Kencana.

Muru`ah, S. (2000). Metodologi Dakwah Kontemporer, Yogyakarta:Mitra Pustaka.

Ni`mah, N. (2016). Dakwah Komunikasi Visual. Islamic Communication Journal, 1 (1), 104-120.

Rijal, S. (2018). Kaum Muda Pecinta Habaib: Kesalehan Popular dan Ekspresi Anak Muda di Ibu Kota, Afkaruna, 14 (2), 166-218.

Rosidi, I. (2020). Anak Muda Muslim di Pekanbaru: Konsumsi, Identitas dan Globalisasi. Madania: Jurnal Ilmu-Ilmu Keislaman, 10 (2), 67-75.

Rosmanah, M. (2013). Pendekatan Halaqoh Dalam Konseling Islam Dengan Coping Stress sebagai Ilustrasi, Intizar, 19 (2), 303-304.

Triantoro, D.A. (2018). Dakwah dan Kesalehan: Studi tentang Gerakan Dakwah Teras Dakwah di Kota Yogyakarta. Jurnal Masyarakat dan Budaya, 20 (2), 273-286.

Hasil wawancara peneliti dengan Cahyo Mahasiswa UIR Riau pada tanggal 3 Maret 2021, Sekretariat FSRMM Pekanbaru.

Hasil wawancara peneliti dengan Efri, Mahasiswa UIN Suska Riau pada tanggal 3 Maret 2021, Sekretariat FSRMM Pekanbaru.

Hasil wawancara peneliti dengan Hajril Aswandi , Ketua FSRMM pada tanggal 3 Maret 2021, Sekretariat FSRMM Pekanbaru.

Hasil wawancara peneliti dengan Lintang Timur, Ketua Devisi Dakwah dan Kaderisasi pada tanggal 3 Maret 2021, Sekretariat FSRMM Pekanbaru.

Hasil wawancara peneliti dengan Tengku Ramadhan Anggota FSRMM pada tanggal 16 Maret 2021, CAFÉ CANDU KOPI Pekanbaru.

Hasil wawancara peneliti dengan Yogi Prasteya, Ketua Devisi Humas dan Aksos pada tanggal 17 Maret 2021, Sekretariat FSRMM Pekanbaru. 